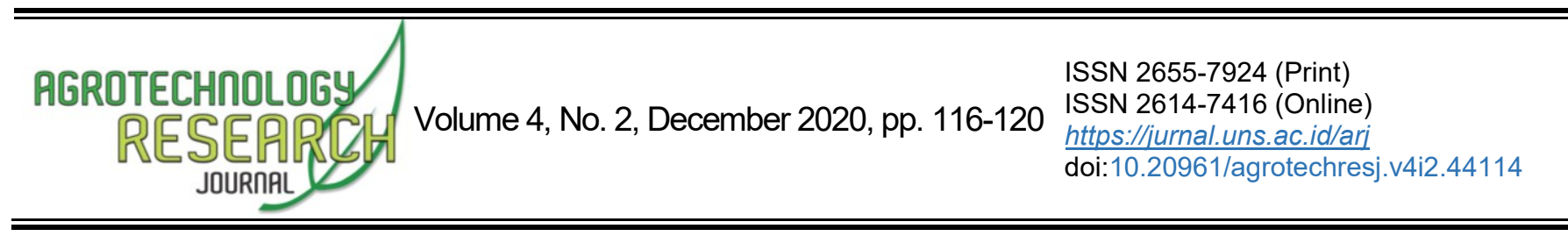

\title{
Produksi Kedelai pada Tumpang Sari dengan Tithonia diversifolia
}

\author{
Putri Mustika Sari' ${ }^{*}$, Adriansyah Yoesoep ${ }^{2}$, Lisdayani ${ }^{3}$ \\ ${ }^{1-3}$ Department of Agrotechnology, Faculty of Agriculture, Universitas Alwashliyah Medan, Sumatera Utara, Indonesia
}

Received 30 August 2020; Accepted 23 November 2020; Published 1 December 2020

\begin{abstract}
Considering that soybeans are a food ingredient, it is necessary to control insect pests that are appropriate and environmentally friendly to increase soybean production, for example, through an intercropping pattern using flowering plants that can attract beneficial insects. This study aimed to increase soybean production by increasing the number of natural enemies planted through an intercropping soybean pattern with Titonia (Tithonia diversifolia). This research was conducted from April - August 2020 at Aras Kabu Village Deli Serdang District; the method used was direct observation to the experimental field of soybean - Titonia intercropping made with 5 Mapping spacing treatments. Harvesting insects using sweep net and for production is counted from soybean pods. The results showed that the soybean-Titonia intercropping had an effect on soybean production, the highest number of seeds was in the treatment of $50 \mathrm{~cm}$ spacing between plants (T4) of 57.33, and the highest weight of 100 seeds was in the treatment of $50 \mathrm{~cm}$ spacing between plants (T4) treatment of 15.22. The insect orders found in the area of Titoniasoybean intercropping plantations are Hemiptera, Coleoptera, Diptera, Hymenoptera, Lepidoptera, where many predatory insects, parasitoids, and pollinators are found. Judging from the content of secondary metabolites of Titonia, namely alkaloids, tannins, and flavonoids, the results of Titonia plants, including flower, stems, and leaves, can be used to extract pesticides in controlling insect pests.
\end{abstract}

Keywords: Legume; Parasitoid; Predator

Cite This As (CSE Style): Sari PM, Yoesoep A, Lisdayani. 2020. Produksi Kedelai pada Tumpang Sari dengan Tithonia diversifolia. Agrotech Res J. 4(2): 116-120. https://doi.org/10.20961/agrotechresj.v4i2.44114

\section{PENDAHULUAN}

Kedelai menjadi kelompok tanaman polong yang dibudidayakan untuk menyediakan bahan pangan pokok dan sumber protein (Zhang et al. 2020). Badan Pusat Statistik (2018) menyebutkan produksi kedelai domestik hanya sebesar 982.598 ton. Sedangkan untuk memenuhi kebutuhan dalam negeri, Indonesia perlu melakukan impor sebanyak 2,6 juta ton. Salah satu kendala dalam peningkatan produksi kedelai adalah adanya serangan hama, dimana kedelai menjadi sasaran serangan hama mulai dari tumbuh hingga menjelang panen (Rahayu et al. 2018).

Menurut Soverda dan Alia (2016) sistem tumpang sari menjadi salah satu teknik budidaya yang tepat untuk meningkatkan produktivitas lahan dan mengurangi risiko gagal panen. Nicholls dan Altieri (2012) bahwa keanekaragaman tumbuhan di dalam dan sekitar area pertanaman dapat menjadi habitat dan menarik bagi serangga bermanfaat sehingga dapat mendorong peningkatan keanekaragaman serta kelimpahan serangga. Berdasarkan hal tersebut, keberadaan

${ }^{*}$ Corresponding Author:

E-Mail: h0lm3s44@gmail.com tumbuhan berbunga dalam agroekosistem sangat diperlukan guna mendukung berfungsinya layanan ekologi (ecological service) (Hikal et al. 2017).

Pengelolaan habitat sekitar lahan pertanian menjadi pilihan sebagai upaya konservasi serangga bermanfaat, misalnya dengan penanaman tumbuhan berbunga (Haight dan Hammill 2020). Tumbuhan berbunga dapat memproduksi nektar dan polen, yang merupakan sumber pakan/pakan tambahan bagi predator, parasitoid dewasa, serta pollinator (Greer et al. 2020; Nakayama dan Asami 2020).

Titonia (Tithonia diversifolia) awalnya dikenal sebagai tumbuhan liar yang sangat agresif membentuk koloni sehingga menjadi gulma bagi tanaman budidaya (Ayesa et al. 2018), tetapi kemudian diketahui bahwa $T$. diversifolia dapat dimanfaatkan sebagai pupuk hijau (Jama et al. 2000; Jorge Mustonen et al. 2012) meningkatkan kesuburan tanah (Mustonen et al. 2014), sebagai pestisida nabati (Akpheokhai dan Fawole 2012). Kandungan metabolit sekunder dari ekstrak Titonia adalah Sesquiterpene lactone, senyawa polifenol (flavonoid dan tannin) dan saponin (Pretti et al. 2018). Bunga, daun, batang dan akar Tithonia mengandung minyak atsiri (Lawal et al. 2012; Green et al. 2017).

Jika $T$. diversifolia dibudidayakan pada lokasi yang berdekatan dengan tempat budidaya tanaman lain, diharapkan bahwa tajuknya dapat dipanen secara 
berkala sehingga dapat digunakan sebagai sumber hara jangka panjang terutama dalam sistem pertanian organik (Desyrakhmawati et al. 2015). Titonia tumbuh cepat, toleran terhadap kerapatan tajuk yang tinggi, dengan perakaran yang dalam, dijadikan sebagai penahan erosi dan sumber bahan organik tanah. Titonia dimanfaatkan sebagai sumber hara $\mathrm{N}$ dan K oleh petani Kenya (Jama et al. 2000; Bagnarello et al. 2009).

Berdasarkan hal di atas menunjukkan bahwa belum adanya penelitian tentang tumpang sari antara kedelai dengan Titonia, maka penelitian ini bertujuan untuk melihat manfaat dari tumpang sari kedelai-Titonia yakni dapat meningkatkan produksi kedelai.

\section{BAHAN DAN METODE}

Penelitian ini telah dilaksanakan dibulan April Agustus 2020 di Areal Pertanian Desa Aras Kabu Kecamatan Beringin Kabupaten Deli Serdang. Metode yang digunakan dalam penelitian ini adalah observasi langsung di lahan percobaan, Lahan percobaan tumpang sari kedelai - Titonia dibuat dengan 5 petakan perlakuan jarak tanam yakni : T1 : Titonia $(50 \mathrm{~cm} \times 40$ $\mathrm{cm})$; T2 : Kedelai $(40 \mathrm{~cm} \times 20 \mathrm{~cm}$ ); T3 : Tumpang Sari (jarak antar tanaman $40 \mathrm{~cm}$ ); T4 : Tumpang Sari (jarak antar tanaman $50 \mathrm{~cm}$ ); T5 : Tumpang Sari (jarak antar tanaman $60 \mathrm{~cm}$ ), jarak tanam tumpang sari yang dibuat mengingat kerapatan tajuk tanaman Titonia dan belum adanya jarak tanam optimal pada budidaya Titonia.

Pengamatan pengambilan sampel serangga di lapangan dilakukan setiap minggu sejak tanaman berumur 2 minggu sampai panen. Perhitungan produksi kedelai yang dihasilkan dari pola tanam tumpang sari kedelai - Titonia dengan cara pengambilan 10\% tanaman sampel secara diagonal pada tiap petakan, kemudian dihitung jumlah polong dan berat 100 biji yang dihasilkan tanaman sampel. Data komponen hasil kedelai dibandingkan secara deskriptif dengan bantuan gambar, untuk mengidentifikasi pengaruh antar perlakuan. Serangga yang datang ke pertanaman tumpang sari kedelai-Titonia dikoleksi dengan menggunakan metode perangkap jaring (Sweep Net), serangga yang dikumpulkan diidentifikasi di Laboratorium Hama dan Penyakit Tanaman USU Medan untuk dilihat ordo serangga. Dan analisis metabolit sekunder dari tanaman Titonia dengan metode uji fitokimia dilakukan di Laboratorium Pasca kimia USU Medan.

\section{HASIL DAN PEMBAHASAN \\ Pengaruh Pola Tanam Tumpang Sari Terhadap Produksi Kedelai}

Hasil penelitian menunjukkan bahwa penanaman tumpang sari kedelai-Titonia berpengaruh terhadap hasil produksi kedelai. Pada Gambar 1 terlihat bahwa pada jumlah biji tertinggi terdapat pada perlakuan jarak antar tanaman $50 \mathrm{~cm}$ (T4) pada tumpang sari kedelai-Titonia yakni sebesar 57,33 . Hal ini menunjukkan bahwa jika tanaman kedelai tidak terlalu rapat dengan Titonia dapat memungkinkan tanaman kedelai tumbuh dengan baik. Sesuai dengan pernyataan Jama et al. (2000) bahwa
Titonia tumbuh cepat, toleran terhadap kerapatan tajuk yang tinggi, dengan perakaran yang dalam, dijadikan sebagai penahan erosi dan sumber bahan organik tanah. Hasil penelitian Cheriere et al. (2020) bahwa kedelai merupakan tanaman yang dapat dibudidayakan dengan sistem tumpang sari. Beberapa penelitian telah menunjukkan peningkatan produksi, stabilitas hasil dan produktivitas kedelai pada sistem tumpang sari dibandingkan dengan sistem monokultur, terutama pada sistem input rendah (Raseduzzaman dan Jensen 2017).

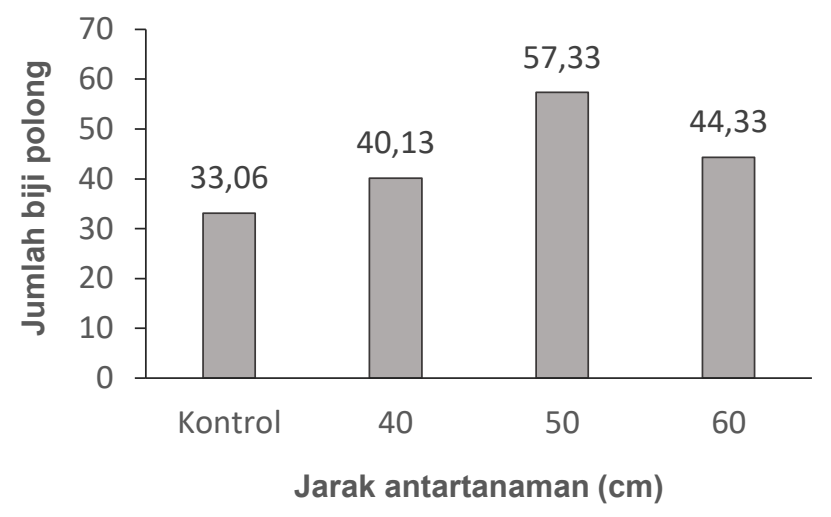

Gambar 1. Jumlah biji polong kedelai

Gambar 1 menunjukkan bahwa pada jumlah biji terendah terdapat pada perlakuan kontrol (T2) pada pertanaman kedelai yakni sebesar 33,06. Hal ini menunjukkan bahwa pada tanaman kedelai tanpa Titonia akan lebih mudah terserang hama. Salah satu yang menyebabkan penurunan produksi kedelai, dikarenakan adanya serangan hama di pertanaman. Menurut Soverda dan Alia (2016) sistem tumpang sari menjadi salah satu teknik budidaya yang tepat untuk meningkatkan produktivitas lahan dan mengurangi risiko gagal panen. Pengelolaan habitat sekitar lahan pertanian menjadi pilihan sebagai upaya konservasi serangga bermanfaat, misalnya dengan penanaman tumbuhan berbunga (Beaumont et al. 2019).

Gambar 2 menunjukkan bahwa berat 100 biji polong kedelai tertinggi juga terdapat pada perlakuan jarak antar tanaman $50 \mathrm{~cm}$ (T4) pada tumpang sari kedelaiTitonia yakni sebesar 15,22. Hal ini dapat dikarenakan pada perlakuan T4 tumpang sari tanaman kedelai dengan Titonia tidak terlalu rapat sehingga memungkinkan polong tidak banyak terserang hama, tanaman terkena cahaya matahari dengan cukup, dan penyebaran unsur hara merata. Hal ini sesuai dengan Reckling et al. (2020) bahwa jarak tanam berperan dalam memanfaatkan cahaya secara efektif, penyebaran unsur hara yang merata, dan penyebaran OPT yang terkendali. Kemudian manfaat lainnya dengan adanya tanaman Titonia memungkinkan berbagai serangga datang ke pertanaman termasuk musuh alami. Keragaman yang tinggi biasanya dapat membuat ekosistem menjadi lebih stabil dan interaksi di dalamnya lebih intens (Yuniar dan Haneda 2015). Keberadaan tumbuhan berbunga sekitar area pertanaman dapat menyediakan nektar dan polen (Nicholls dan Altieri 2013). 


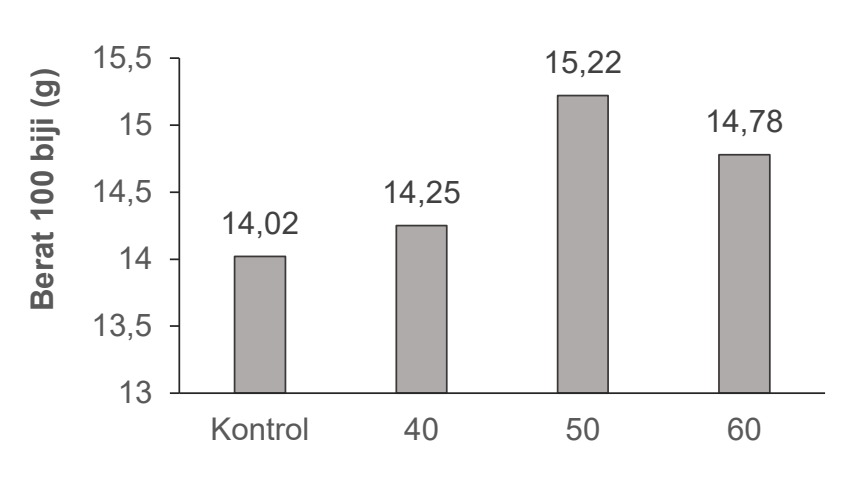

Jarak antartanaman (cm)

Gambar 2. Berat 100 biji polong kedelai

Selisih produksi jumlah biji polong perlakuan kedelai tanpa Titonia (T2) 21,27 lebih besar dibandingkan perlakuan Tumpang Sari kedelai - Titonia (jarak antar tanaman $50 \mathrm{~cm} / \mathrm{T} 4$ ), memperlihatkan bahwa produksi kedelai tanpa Titonia lebih kecil dibandingkan pada produksi kedelai tumpang sari dengan Titonia, dimana penanaman kedelai dengan habitat yang beragam dapat meningkatkan keragaman pada serangga. Hail ini sesuai dengan Hartoyo et al. (2016) bahwa sistem tumpang sari dapat mengoptimalkan penggunaan hara, air dan sinar matahari, seefisien mungkin untuk mendapatkan produksi yang optimal. Heimoana et al. (2017) bahwa keanekaragaman tumbuhan di dalam dan sekitar area pertanaman dapat menjadi habitat dan menarik bagi serangga bermanfaat sehingga dapat mendorong peningkatan keanekaragaman serta kelimpahan serangga. Berdasarkan hal tersebut, keberadaan tumbuhan berbunga dalam agroekosistem sangat diperlukan guna mendukung berfungsinya layanan ekologi (ecological service) (Luo et al. 2020).

Penggunaan Titonia sebagai tanaman tumpang sari dengan kedelai lebih bermanfaat dalam meningkatkan produksi kedelai dibandingkan penggunaan Titonia jika diekstrak bagian daunnya untuk dijadikan pupuk organik. Hal ini sesuai dengan Ayu dan Lestari (2016) bahwa Titonia akan membentuk senyawa yang bersifat alelopati terhadap tanaman budidaya, dapat menghambat perkecambahan dan pertumbuhan benih. Aktivitas alelopati daun paitan dipengaruhi oleh waktu dekomposisi, aktivitas mikroorganisme, dan daya serap tanah terhadap zat-zat penghambat pertumbuhan (Rahayu et al. 2018).

\section{Serangga Pengunjung Pada Tumpang Sari Kedelai- Titonia}

Serangga yang ditemukan di areal pertanaman tumpang sari kedelai Titonia diidentifikasi sampai ordo yakni Hemiptera, Coleoptera, Diptera, Hymenoptera, Lepidoptera. Hal ini menunjukkan bahwa selain serangga hama terdapat juga serangga predator dan penyerbuk dalam areal pertanaman tumpang sari, diduga dengan adanya pengaruh bunga tanaman Titonia yang menarik serangga lainnya untuk datang dan adanya kandungan senyawa metabolit sekunder yang terkandung dalam tanaman Titonia sehingga menarik serangga (Grdisa dan Gršić 2013). Chmura et al. (2013) melaporkan bahwa ekosistem dengan tumbuhan berbunga yang lebih beragam akan lebih memikat serangga bermanfaat.

\section{Kandungan Metabolit Sekunder Terhadap Pemanfaatan Tanaman Titonia}

Pada hasil uji metabolit sekunder melalui uji fitokimia diketahui bahwa tanaman Titonia mengandung Alkaloid, Flavonoid, dan tanin (Tabel 1). Hal tersebut menunjukkan bahwa tanaman Titonia juga dapat dimanfaatkan baik dari segi bunga, daun, dan batang sebagai insektisida nabati, sehingga tanaman Titonia sudah layak untuk dibudidayakan. Menurut Essien et al. (2018) bahwa flavonoid merupakan senyawa metabolit sekunder penting pada tanaman yang berfungsi sebagai penolak (deterrent), penghambat makan (anti-feeding) dan bersifat racun (toxicosis) bagi serangga. Kandungan metabolit sekunder dari ekstrak minyak mentah Tithonia adalah Sesquiterpene lactone, senyawa polifenol (flavonoid dan tannin) dan saponin (Bagnarello et al. 2009; Ayesa et al. 2018). Bunga, daun, batang dan akar Titonia mengandung minyak atsiri (Chukwuka et al. 2007; Lawal et al. 2014). Kandungan metabolit sekunder dapat dilihat pada Tabel 1.

Tabel 1. Kandungan metabolit sekunder tanaman Titonia

\begin{tabular}{lccc}
\hline \multirow{2}{*}{ Jenis Metabolit Sekunder } & \multicolumn{3}{c}{ Bagian Tanaman } \\
\cline { 2 - 4 } & Bunga & Daun & Batang \\
\hline Alkaloid & + & + & + \\
Flavonoid & + & + & + \\
Tanin & + & + & + \\
\hline
\end{tabular}

Keterangan: $(+)$ : ada

\section{KESIMPULAN}

Tumpang sari tanaman kedelai - Titonia dengan jarak antar tanaman $50 \mathrm{~cm}$ (T4) berpengaruh meningkatkan produksi kedelai, terlihat dari jumlah biji sebesar 57,33 dan berat 100 biji polong kedelai sebesar 15,22 . Selain itu terdapat juga serangga musuh alami yang datang berkunjung ke pertanaman tumpang sari Titonia-kedelai adalah serangga parasitoid dari Ordo Hymenoptera, dan serangga predator anggota Ordo Coleoptera, sehingga serangga hama dapat dikendalikan secara alami. Hasil dari budidaya Titonia pun dapat dimanfaatkan dari segi bunga, daun dan batangnya sebagai ekstrak pestisida nabati karena mengandung alkaloid, tanin dan flavonoid.

\section{UCAPAN TERIMA KASIH}

Pelaksanaan penelitian ini mendapatkan bantuan dana dari Program Penelitian Dasar Pemula (PDP) KEMENRISTEK DIKTI, Medan, dengan nomor kontrak: 42/LL1/PG/2020.

\section{DAFTAR PUSTAKA}

Akpheokhai IL, Fawole B. 2012. Evaluation of Some Plant Extracts for the Management of Meloidogyne incognita on Soybean ( Glycine max ). 8(4):429-435. doi:10.5829/idosi.wjas.2012.8.4.1658.

Ayesa SA, Chukwuka KS, Odeyemi OO. 2018. Tolerance of Tithonia diversifolia and Chromolaena odorata in heavy metal simulated-polluted soils and three selected dumpsites. Toxicol Reports. 5(October):1134-1139. doi:10.1016/j.toxrep.2018.11.007. 
Ayu S, Lestari D. 2016. Pemanfaatan Paitan (Tithonia diversifolia) sebagai Pupuk Organik pada Tanaman Kedelai. Iptek Tanam Pangan. 11(1):49-56.

Badan Pusat Statistik. 2018. Statistik Pertanian. Susanti AA, Waryanto B, editors. Jakarta: Pusat Data dan Sistem Informasi Pertanian, Kementerian Pertanian Republik Indonesia.

Bagnarello G, Hilje L, Bagnarello V, Cartín V, Calvo M. 2009. Actividad fagodisuasiva de las plantas tithonia diversifolia y montanoa hibiscifolia (asteraceae) sobre adultos del insecto plaga bemisia tabaci (homoptera: Aleyrodidae). Rev Biol Trop. 57(4):1201-1215. doi:10.15517/rbt.v57i4.5457.

Beaumont LJ, Esperón-Rodríguez M, Nipperess DA, Wauchope-Drumm M, Baumgartner JB. 2019. Incorporating future climate uncertainty into the identification of climate change refugia for threatened species. Biol Conserv. 237(July):230-237. doi:10.1016/j.biocon.2019.07.013.

Cheriere T, Lorin M, Corre-Hellou G. 2020. Species choice and spatial arrangement in soybean-based intercropping: Levers that drive yield and weed control. F Crop Res. 256(March):107923. doi:10.1016/j.fcr.2020.107923.

Chmura D, Adamski P, Denisiuk Z. 2013. How do plant communities and flower visitors relate? A case study of semi-natural xerothermic grasslands. Acta Soc Bot Pol. 82(2):99-105. doi:10.5586/asbp.2013.015.

Chukwuka KS, Ogunyemi S, Fawole I. 2007. Ecological distribution of Tithonia diversifolia (Hemsl). A. Gray-A new exotic weed in Nigeria. J Biol Sci. 7(5):709-719. doi:10.3923/jbs.2007.709.719.

Desyrakhmawati L, Melati M, , S, Hartatik W. 2015. Pertumbuhan Tithonia diversifolia dengan Dosis Pupuk Kandang dan Jarak Tanam yang Berbeda. J Agron Indones (Indonesian J Agron. 43(1):72-80. doi:10.24831/jai.v43i1.9595.

Essien EE, Ascrizzi R, Flamini G. 2018. Characterization of volatile metabolites of Tithonia diversifolia ( Hemsley ) A . gray leaves and flowers. Am J Essent Oils Nat Prod. 6(2):19-21.

Grdiša M, Gršić K. 2013. Botanical insecticides in plant protection. Agric Conspec Sci. 78(2):85-93.

Green PWC, Belmain SR, Ndakidemi PA, Farrell IW, Stevenson PC. 2017. Insecticidal activity of Tithonia diversifolia and Vernonia amygdalina. Ind Crops Prod. doi:10.1016/j.indcrop.2017.08.021.

Greer AW, Van Wyk JA, Hamie JC, Byaruhanga C, Kenyon F. 2020. Refugia-Based Strategies for Parasite Control in Livestock. Vet Clin North Am Food Anim Pract. 36(1):31-43. doi:10.1016/j.cvfa.2019.11.003.

Haight J, Hammill E. 2020. Protected areas as potential refugia for biodiversity under climatic change. Biol Conserv. 241(May 2019):1-11. doi:10.1016/j.biocon.2019.108258.
Hartoyo APP, Siregar IZ, Supriyanto, Prasetyo LB, Thelaide I. 2016. Biodiversity, Carbon Stocks and Community Monitoring in Traditional Agroforestry Practices: Preliminary Results from Two Investigated Villages in Berau, East Kalimantan. Procedia Environ Sci. 33:376-385. doi:10.1016/j.proenv.2016.03.088.

Heimoana V, Pilkington LJ, Raman A, Mitchell A, Nicol HI, Johnson AC, Gurr GM. 2017. Integrating spatially explicit molecular and ecological methods to explore the significance of non-crop vegetation to predators of brassica pests. Agric Ecosyst Environ. 239:12-19. doi:10.1016/j.agee.2017.01.008.

Hikal WM, Baeshen RS, Said-Al Ahl HAH. 2017. Botanical insecticide as simple extractives for pest control. Cogent Biol. 3(1). doi:10.1080/23312025.2017.1404274.

Jama B, Palm CA, Buresh RJ, Niang A, Gachengo C, Nziguheba G, Amadalo B. 2000. Tithonia diversifolia as a green manure for soil fertility improvement in western Kenya: A review. Agrofor Syst. 49(2):201221. doi:10.1023/A:1006339025728.

Jorge Mustonen P, Oelbermann M, Kass DCL. 2012. Using Tithonia diversifolia (Hemsl.) Gray in a Short Fallow System to Increase Soil Phosphorus Availability on a Costa Rican Andosol. J Agric Sci. 4(2):91-100. doi:10.5539/jas.v4n2p91.

Lawal OA, Kasali AA, Opoku AR, Oyedeji AO. 2012. Volatile constituents of the flowers, leaves, stems and roots of Tithonia diversifolia (Hemsely) A. Gray. J Essent Oil-Bearing Plants. 15(5):816-821. doi:10.1080/0972060X.2012.10644125.

Luo D, Silva DP, De Marco Júnior P, Pimenta M, Caldas MM. 2020. Model approaches to estimate spatial distribution of bee species richness and soybean production in the Brazilian Cerrado during 2000 to 2015. Sci Total Environ. 737:139674. doi:10.1016/j.scitotenv.2020.139674.

Mustonen PSJ, Oelbermann M, Kass DCL. 2014. Response of the common bean (Phaseolus vulgaris L.) to Tithonia diversifolia (Hamsl.) Gray biomass retention or removal in a slash and mulch agroforestry system. Agrofor Syst. 88(1):1-10. doi:10.1007/s10457-013-9650-9.

Nakayama A, Asami K. 2020. Mechanism of maintaining cobble-bar vegetation and the geomorphic conditions for existence of refugia during large floods. J HydroEnvironment Res. 30(March):91-99. doi:10.1016/j.jher.2020.03.003.

Nicholls Cl, Altieri MA. 2013. Plant biodiversity enhances bees and other insect pollinators in agroecosystems. A review. Agron Sustain Dev. 33(2):257-274. doi:10.1007/s13593-012-0092-y.

Pretti IR, Luz AC da, Jamal CM, Batitucci M do CP. 2018. Variation of biochemical and antioxidant activity with respect to the phenological stage of Tithonia diversifolia Hemsl. (Asteraceae) populations. Ind Crops Prod. 121(January):241-249. doi:10.1016/j.indcrop.2018.04.080. 
Rahayu SK, Supriyadi S, Supriyono S, Wijayanti R, Putri RBA, Putri RBA. 2018. Keanekaragaman serangga pengunjung bunga pada tanaman tumpang sari kedelai dengan tanaman orok-orok (Crotalaria juncea). J Entomol Indones. 15(1):23. doi:10.5994/jei.15.1.23.

Raseduzzaman M, Jensen ES. 2017. Does intercropping enhance yield stability in arable crop production? A meta-analysis. Eur J Agron. 91(September):25-33. doi:10.1016/j.eja.2017.09.009.

Reckling M, Bergkvist G, Watson CA, Stoddard FL, Bachinger J. 2020. Re-designing organic grain legume cropping systems using systems agronomy. Eur J Agron. 112(December 2018):125951. doi:10.1016/j.eja.2019.125951.
Soverda N, Alia Y. 2016. Sistem Pertanaman Tumpangsari Antara Beberapa Genotip Kedelai (Glycine max (L) Merill) Dengan Jagung Manis (Zea mays Var. Saccharatasturt) Yang Ditanam Secara Multi Rows. J Agrium Unimal. 13(2):27-34.

Yuniar N, Haneda NF. 2015. Keanekaragaman semut (Hymenoptera: Formicidae) pada empat tipe ekosistem yang berbeda di Jambi. In: Prosiding Seminar Nasional Masyarakat Biodiversitas Indonesia. Vol. 1 (7). p. 1582-1585.

Zhang R, Mu Y, Li X, Li S, Sang P, Wang X, Wu H, Xu N. 2020. Response of the arbuscular mycorrhizal fungi diversity and community in maize and soybean rhizosphere soil and roots to intercropping systems with different nitrogen application rates. Sci Total Environ. 740:139810. doi:10.1016/j.scitotenv.2020.139810. 